\title{
Combining Historical and Ecological Knowledge to Optimise Biodiversity Conservation in Semi-Natural Grasslands
}

\author{
Eva Gustavsson'1 , Anna Dahlström², Marie Emanuelsson³, \\ Jörgen Wissman ${ }^{2}$ and Tommy Lennartsson ${ }^{2}$ \\ ${ }^{1}$ Lake Vänermuseum of Natural and Cultural Sciences, Lidköping \\ ${ }^{2}$ The Swedish Biodiversity Centre, Uppsala \\ ${ }^{3}$ Research and Innovation Service, University of Gothenburg, \\ Gothenburg \\ Sweden
}

\section{Introduction}

The species-rich semi-natural grasslands, i.e. unfertilised, uncultivated pastures and hay meadows, are among the most threatened habitats in the European agricultural landscape. Most European countries have lost more than $90 \%$ of their semi-natural grasslands due to abandonment or productivity intensification during the last century (Bernes, 1993; Piessens \& Hermy, 2006; Stanners \& Bourdeau, 1995). This drastic loss of habitat has caused population declines and extinctions of large numbers of grassland species (Baillie, 2004; Cheffings \& Farrel, 2005; Gärdenfors, 2010). To stop further declines of grassland species, habitats and cultural values, national and EU subsidiary programmes pay farmers to uphold and reintroduce management of semi-natural grassland (European Union, 2011; Kleijn \& Sutherland, 2003; Myrdal, 2001). To merit the payment, certain management criteria have to be fulfilled, e.g. in Sweden mainly aiming at minimising litter accumulation and shrub encroachment in the grassland (Swedish Board of Agriculture, 2007).

A growing number of studies express concern that these conservation efforts, and the current grassland management in general, are not sufficiently reaching the conservation goals, i.e. to rescue threatened grassland organisms and ecological functionality of the habitats. Invertebrates, birds and management-dependent vascular plants in particular have been reported to decline in spite of ongoing grassland management for conservation purposes (e.g. Boschi \& Baur, 2007; Bühler \& Schmid, 2001; Kruess \& Tscharntke, 2002; Öckinger et al., 2006; Söderström et al., 2001; Willcox et al., 2010). Ecologically insufficient management quality is a potential threat to semi-natural grasslands that has attracted considerably less attention than has the cessation of management.

The species-richness in semi-natural grassland is to a large extent a legacy of historical agricultural practices (Bruun et al., 2001; Pykälä, 2000; Reitalu et al., 2010). The agricultural system preceding the modernisation processes in Sweden and other countries in north 
Europe, i.e. mixed farming (Grigg, 1974), formed a wide range of grassland habitats and disturbance regimes through a variety of land-use practices, differing in terms of type, timing, intensity and dynamics of disturbance. Common main types of land use were grazing, mowing, burning and irrigation. Grassland ecosystems were central in this system as a base for livestock husbandry and for nutrients, which were reallocated from pastures and hay meadows to the permanent arable fields through livestock manure (Emanuelsson, 1988). In Scandinavia this system was established around AD 800-1000 (Welinder et al., 1998). It remained until a new agricultural system was introduced, between c. 1860 and 1950, which was based on artificial fertilisers as the nutrient base (Gadd, 2000).

The main types of historical grassland use in Europe was grazing for summer forage and mowing for winter fodder, both constituting a, more or less, yearly biomass removal. This causes nutrient depletion or reallocation, reduction of vegetation height and damage to plants. Competition patterns between plant species thus generally favour low-competitive species because the disturbance counteracts the succession towards taller and more speciespoor vegetation (Elisseou et al., 1995; Plantureux, 1996). Lower vegetation increases ground sun exposure and reduces litter thickness, favouring seed germination and ground arthropods. Damage to plants reduces flowering and seed production of plants, in turn negatively affecting e.g. insects dependent on seeds, nectar and pollen. The net effects on grassland vegetation largely depend on timing, intensity and variability of management. Thus, different anthropogenic land-use regimes may be considered as analogous to different natural disturbance regimes (Pykälä, 2000), creating a set of ecological conditions which are the basic prerequisites for grassland biodiversity.

This chapter discusses management quality in an ecological-historical context. It relies on the basic assumptions that current grassland biodiversity is largely a legacy of past land use, that species still present in a grassland have the same ecological needs today as historically (Lennartsson \& Linkowski, 2011), and that biodiversity therefore is favoured by management practices which are ecologically similar to the historical practices, and threatened by management that ecologically differ from the historical conditions. For example, Gustavsson et al. (2007) found that the switch of management from mowing to grazing around one century ago had been equally detrimental to the number of grassland plant species (cf. Fischer \& Wipf, 2002) as had around four decades of abandonment. In order to design conservation management for habitats that are formed by historical land use we thus need to know which land-use components that were present historically, and which of the components that are ecologically significant and therefore need to be reintroduced or imitated in today's management.

We identify ecological variables related to type, intensity, timing, and dynamics of disturbance and discuss how these variables are related to the historical use of grasslands compared to the current management practices. We address the following questions: 1) Which necessary ecological variables in semi-natural grasslands can be identified, based mainly on plant life cycles? 2) How may different components of the pre-industrial grassland use have corresponded to the identified ecological variables? 3) What are the qualitative and quantitative differences between the current and the historical landscape in terms of the landscape's content of ecologically critical management components? 4) How can differences between past and current grassland management be expected to affect grassland biodiversity, and which are the implications for future management and restoration of species-rich grasslands? 


\section{Study regions and methods}

\subsection{Study regions}

The study concerns 66 villages in five regions in southern Sweden, covering in all 18,620 hectares (Table 1, Fig. 1). The climate is rather similar between the regions: annual mean temperature ranges from 5 to $6{ }^{\circ} \mathrm{C}$, yearly precipitation is around $600 \mathrm{~mm}$, and the vegetation period is 180-190 days (National Atlas of Sweden, 1995).

\begin{tabular}{|c|c|c|c|c|c|}
\hline $\begin{array}{l}\text { Name of } \\
\text { region }\end{array}$ & $\begin{array}{l}\text { Lat. } \\
\text { Long. }\end{array}$ & $\begin{array}{l}\text { Area } \\
\text { (ha) }\end{array}$ & $\begin{array}{l}\text { Upland or } \\
\text { lowland }\end{array}$ & Soil properties & $\begin{array}{l}\text { Main historical } \\
\text { agricultural production }\end{array}$ \\
\hline $\begin{array}{l}\text { Källstorp/ } \\
\text { Söne }\end{array}$ & $\begin{array}{l}58^{\circ} 50^{\prime} \mathrm{N} \\
12^{\circ} 91^{\prime} \mathrm{E}\end{array}$ & 1100 & Mosaic & $\begin{array}{l}\text { Clay and thin } \\
\text { till }\end{array}$ & Livestock $^{1}$ \\
\hline Selaön & $\begin{array}{l}59^{\circ} 25^{\prime} \mathrm{N} \\
17^{\circ} 12^{\prime} \mathrm{E}\end{array}$ & 4084 & Lowland & Clay and till & Grain² \\
\hline Kristberg & $\begin{array}{l}58^{\circ} 34^{\prime} \mathrm{N} \\
15^{\circ} 13^{\prime} \mathrm{E}\end{array}$ & 3912 & Upland & Clay and till & Livestock $^{2}$ \\
\hline Fornåsa & $\begin{array}{l}58^{\circ} 29^{\prime} \mathrm{N} \\
15^{\circ} 14^{\prime} \mathrm{E}\end{array}$ & 1604 & Lowland & $\begin{array}{l}\text { Limey clay and } \\
\text { till }\end{array}$ & Grain $^{2}$ \\
\hline Alseda & $\begin{array}{l}57^{\circ} 25^{\prime} \mathrm{N} \\
15^{\circ} 15^{\prime} \mathrm{E}\end{array}$ & 7920 & Upland & $\begin{array}{l}\text { Till with fine } \\
\text { soil fractions }\end{array}$ & Livestock $^{2}$ \\
\hline
\end{tabular}

${ }^{1}$ Jansson, 1998;

2 Dahlström, 2006a

Table 1. Basic information about the five study regions

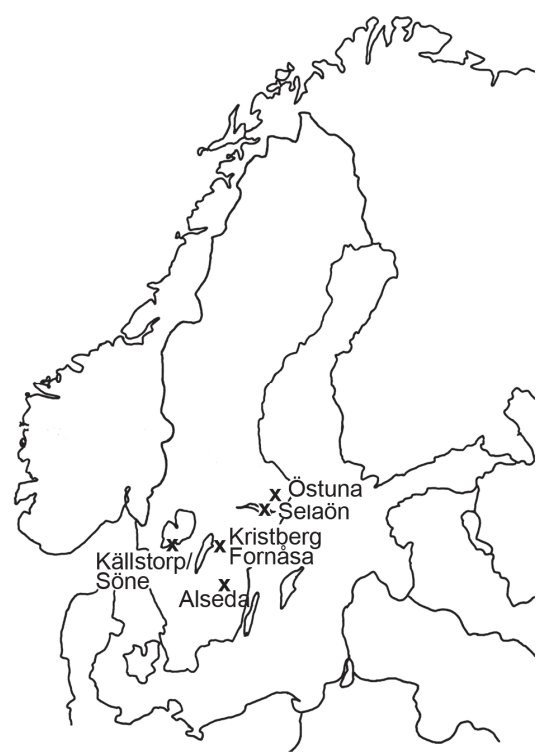

Fig. 1. Study regions. Kristberg and Fornåsa share the same position mark. Östuna study region was used only for estimating current stocking density (see section 2.3). 


\subsection{Definitions}

For a systematic use of grassland management vocabulary, we have decided to use the following: Land use is reserved for the historical conditions, when grasslands were "used" as a necessary part of the livelihood. Management is used for the current conditions, when grasslands are artificially "kept" for conservation purposes. Land-use/management type is used for the main division between grazing and haymaking, which historically were the dominating types of grassland use in the study regions. Land-use/management regime is the systematic application of different variants of grazing or haymaking. Historically the land-use regimes were governed by the agricultural system and in the study regions they occurred in hay meadows (including pasture fenced with hay meadow), permanent pastures and grassland (mainly pasture) enclosed with arable fields. A range of variants of these main regimes existed historically, consisting of either a certain type being applied in the same way every year, or varying in type, timing and intensity more or less systematically between years. The regimes can then be subdivided into landuse/management components, thus comprising the smallest unit in the regimes. A component may be unique to one of the two types, such as handling of hay, or may be applicable in both, such as aspects of management timing. The land-use/management components create, or otherwise affect, the conditions for plants and animals in the grassland habitats. Different habitat conditions are denoted ecological factors, for example microclimate, soil properties and habitat processes such as disturbance of the vegetation by grazing or mowing. The term traditional is only used in the cases where local, current practices can be reasonably expected to be the same as the historical practices.

\begin{tabular}{|l|l|l|l|}
\hline & 18th century & Current & Example \\
\hline $\begin{array}{l}\text { Type } \\
\text { Regime }\end{array}$ & $\begin{array}{l}\text { Land-use } \\
\text { Land-use }\end{array}$ & $\begin{array}{l}\text { Management } \\
\text { Management }\end{array}$ & $\begin{array}{l}\text { Grazing, mowing } \\
\text { Full-season grazing, alternating } \\
\text { mowing and grazing } \\
\text { Late onset of grazing, handling of } \\
\text { hay, weak grazing intensity }\end{array}$ \\
\hline
\end{tabular}

Table 2. Terms used in the chapter, as defined in the text above

\subsection{Methods}

First, literature on grassland management, historical land-use regimes, grassland plants, and grassland vegetation was examined in order to identify ecological factors necessary for grassland plants and components of historical grassland use that created these factors. "Historical" in this case refers to the $18^{\text {th }}$ century, unless differently stated. Ecologically, grassland management can be viewed as a disturbance to the vegetation and single plant individuals, and identification of necessary ecological factors and land-use components was based mainly on how disturbance affects the main steps in the life cycle of grassland plants. The components comprise different aspects of timing, intensity and dynamics of management.

Secondly, the likely abundances of the identified land-use/management components in the five regions were analysed, qualitatively and quantitatively, for both current and historical conditions. For some components this could be done by quantifying the area of grassland managed by the main land-use/management regimes, which provide different combinations of land-use/management components related to timing, intensity and 
dynamics of management. Historical abundances were estimated using large-scaled historical maps (typically 1:4000 and 1:5000) that depict the agricultural system in detail (Kain \& Baigent, 1992; Tollin, 1991). All 66 villages were thus analysed (Archival references: Aurell, 1787; Dahlström, 2006a, p. 277; Hierpe, 1712). Current abundances of these management regimes were estimated by measuring the areas based on information from TUVA, a national database on Swedish semi-natural grasslands, where management type and status of each grassland is recorded (Swedish Board of Agriculture, 2011).

More thorough quantifications of some land-use components could be done by using historical data available for one or a few of the study regions. For Selaön the $18^{\text {th }}$ century grazing intensity was estimated by relating pasture size to the data on livestock type and numbers provided by the land surveyor for each pasture. Livestock data was converted to grazing equivalents according to Dahlström (2006a, pp. 87-89) to allow for comparisons of stocking densities irrespective of livestock type. To compare with current stocking densities, a dataset from Östuna parish, Uppland County, was used. In 2003 the individual areas of 28 pastures were measured by means of GIS and the livestock owners provided data on livestock numbers in each pasture. Current and $18^{\text {th }}$ century size distribution of permanent pastures in the five regions was compared. Current data was extracted from TUVA, whereas historical sizes were measured on $18^{\text {th }}$ century maps.

\subsection{Interpretation of historical maps}

Due to their characteristics, accessibility and extensive geographic cover, historical cadastral maps is the most widely used historical source in Sweden addressing landscape research related to pre-industrial times. There are large scale cadastral maps showing land use from early $17^{\text {th }}$ century onwards (Tollin, 2004). The interpretation of cadastral maps relies on a number of historical source critical aspects. Desired information may not be available and the image accuracy may be seductive, leading to over-interpretations. Furthermore the intentions behind the production of maps changed through time, affecting what type of information was included. Eighteenth century maps were generally created for cadastral information or as tools to modernise the agricultural system. Ephemeral features, e.g. temporary arable fields or pastures, were therefore mostly omitted. Hence, these maps can be viewed as representations of the main spatial arrangement of land use during a much longer time period than the specific years they were made. The maps in this study represent a period spanning the time of the first enclosure act in mid-18th century (in Swedish: storskifte, see Gadd, 2000) and back several centuries, due to the relative stability of the village organisation (Riddersporre, 1995; cf. Sporrong, 1971). Land-use components at an ecologically relevant degree of detail are rarely directly shown by the maps, but need to be derived through historical-ecological interpretation. This study uses information about main land use, spatial relation to other land-use types (as shown by fencing) and areas in order to interpret land-use regimes and ecologically relevant land-use components. The land-use regimes depicted in the maps can be expected to have been present before and after the studied century. Data from other historical sources have therefore been used, mainly from the $17^{\text {th }}$ and $19^{\text {th }}$ centuries to support our interpretations.

\section{Results}

In the five study regions, an area of 15,563 hectares of semi-natural grassland was in use in the $18^{\text {th }}$ century. Of this, only 685 hectares remain today, thus a decrease by almost $96 \%$. In 
addition, the different land-use regimes have decreased disproportionately (Fig. 2). Seven different variants of the main land-use regimes were identified (Fig. 2) in the historical landscape of the study regions, today almost all remaining grassland consists of permanent pasture. Pasture enclosed with arable fields or hay meadows has disappeared completely and mowing with aftermath grazing has decreased by $99.7 \%$.

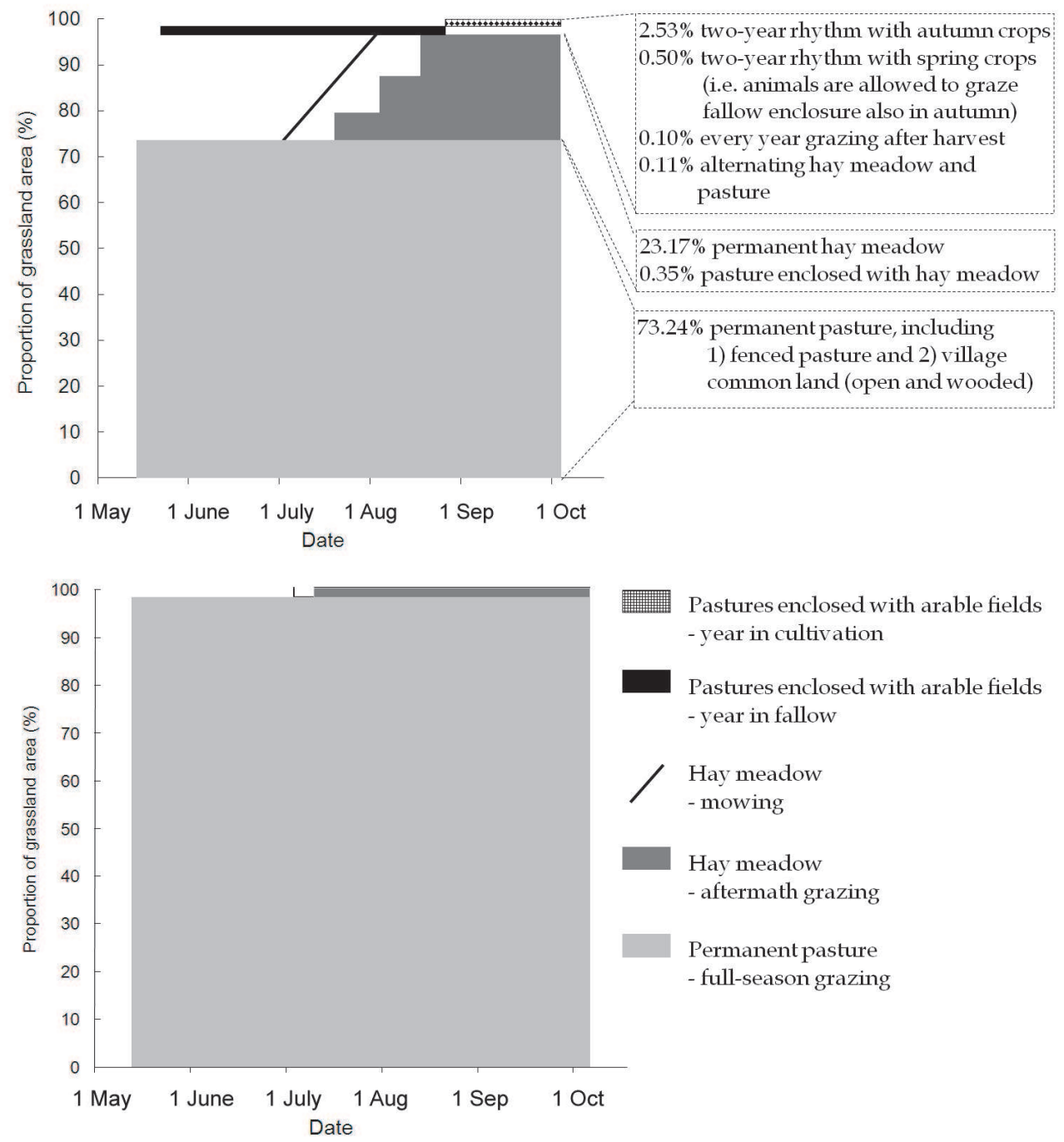

Fig. 2. The proportion of the total area of managed grassland subject to different land-use regimes in the $18^{\text {th }}$ century (upper panel) and management regimes today (lower), and the temporal extension of the regimes over the growing season. Total grassland area in the $18^{\text {th }}$ century, 15,6 hectares; today, 685 hectares. Aftermath grazing is depicted with three steps, symbolising that one hay meadow at a time is opened for grazing 


\subsection{Timing of management}

Management timing refers to when the disturbance of the vegetation occurs, thereby dictating e.g. how much the vegetation is able to grow before the disturbance and which stage of the life cycle of a species that is affected by the disturbance.

\subsubsection{Ecological significance of timing of disturbance}

Timing of disturbance affects seed production, because it is the main factor deciding the proportion of plants that will have time to flower and set seeds before disturbance. An early onset of grazing (April, May) and which continues throughout the season restricts flowering and seed production of vascular plants (Brys et al., 2004; Lennartsson \& Oostermeijer, 2001). The seeds of the majority of grassland plant species ripen between late July to mid August (Dahlström et al., 2008; Wissman, 2006). Even small adjustments of the timing of disturbance within this time window will have large effects on seed production (cf. Jantunen et al., 2007; Oostermeijer et al., 2002; Wissman, 2006), especially in cool summers, when the ripening of seeds is slow (Svensson \& Carlsson, 2005).

Late disturbance on the other hand, reduces the viability of small plant species, seedlings and juvenile rosettes by forcing them to grow in tall vegetation for much of the summer (Brys et al., 2005; Lanta et al., 2009; Lennartsson \& Oostermeijer, 2001). Late onset of grazing may also reduce the proportion of biomass removed during a growth season, because old vegetation to some extent is rejected by the grazers (Bailey et al., 1998).

Grassland plants cope with damage by tolerance mechanisms decreasing the negative effects of damage or avoid damage by resistance (or defence) mechanisms aiming at decreasing the degree of damage (Rosenthal \& Kotanen, 1994). A common tolerance mechanism is regrowth of new flowers and branches after damage (Lennartsson et al., 1997) and is related to timing of damage (Lennartsson et al., 1998). Timing of mowing has likely caused the development of early and late flowering ecotypes. Whereas early flowering ecotypes are sensitive to damage before the seeds mature, late flowering ecotypes need early enough damage to regrow and set seeds afterwards (Simán \& Lennartsson, 1998).

\subsubsection{Management components affecting timing of disturbance}

All treatments included in haymaking - spring raking, mowing and grazing of aftermath occurred historically in a specific sequence from April to September, each interspaced by a shorter or longer resting period (e.g. Arrhenius \& Lindquist, 1904; Ohlsson, 2006). Hay meadows were historically mown during a certain mowing period, often c. one month of length and starting in late June to mid July (Dahlström et al., 2008; Vestbö-Franzén, 2004, pp. 171-172). The process of mowing is swift and non-selective; hence the timing of disturbance within each meadow unit is roughly equal to the mowing onset of that meadow. However, the onset of management differed with about one month from the first to the last meadow. The drying of the grass has been shown to allow some immature seeds to ripen, thereby increasing the seed output similar to a later onset of mowing (Lennartsson, 2003).

Historically, hay meadow enclosures could include unproductive areas not subject to mowing, such as stony and dry areas. These areas were probably not grazed until the meadows were opened for aftermath grazing after the harvest of hay. Pastures in meadow enclosures thus experienced a later disturbance than the meadows themselves, in particular considering that it takes some time after onset of grazing until the vegetation is grazed off, Even later onset of grazing occurred in pastures enclosed with arable fields, in which grazing could not start until after the crop harvest (Fig. 2). 
In permanent pastures, the grazing season in late 19th century lasted from late May/early June to late September/early October, according to ethnological sources (Dahlström et al., 2008; Israelsson, 2005, pp. 192-193). The timing of disturbance to the vegetation in such pastures is largely governed by size of enclosure and grazing intensity. In small enclosures, timing of disturbance on the patch level will be close to the timing of grazing onset, i.e. the vegetation is grazed off within a few days after the animals are let out. Larger enclosures take longer to graze off, which creates a variation in timing of disturbance between patches within the pasture (Brunsell, 2002). Also manual direction of grazing through herding and fencing affected timing of disturbance and created variation both within the pastures during the season (Kardell, 2006) and between pastures (Dahlström, 2010).

\subsubsection{Historical and current timing of management in the study regions}

Historically, late disturbance mainly occurred in hay meadows, but likely also in pastures fenced with arable fields. In the $18^{\text {th }}$ century, about $23 \%$ of the grassland area consisted of hay meadows, i.e. late disturbance (Fig. 2). Another $3 \%$ was pastures fenced together with hay meadow or arable fields and thus likely being grazed late. This was e.g. to be found in Alseda, where every-year cultivation was employed, indicating that pastures enclosed with the arable fields were grazed very late every year. Hay meadow area has decreased by $99.7 \%$ and today only c. $2 \%$ of the currently managed grassland area is subject to late onset of management, all of which by mowing (Fig. 2).

The historical tradition of drying the hay is not generally used in today's conservation mowing (Overud \& Lennartsson, 2004), but is since 2008 liable for extra subsidies and is now applied in c. $10 \%$ of the Swedish hay-meadows with special botanical values (Swedish Board of Agriculture, pers. comm.).

Seeing as timing of disturbance at the patch level in permanent pastures is largely a function of pasture size, a comparison between current and historical size distribution was made. The 600 pastures existing in the 18 th century study areas ranged between 0.07 and 710 ha (mean 18.1, median 6.0 ha), whereas the current 210 pastures ranged between 0.1 and 24 ha (mean 3.2, median 1.9). Although the smallest sized pasture was found in the $18^{\text {th }}$ century landscape, the higher historical mean, median and maximum values in the size distribution imply a later mean timing of disturbance in the pastures historically (Fig. 3). One source critical aspect of the current pasture size is that the database provides data on semi-natural grassland area, not size of enclosure. This dataset should thus be viewed as an indication of enclosure size.

Manual herding has been common in Sweden since at least medieval times (Kardell, 2006; Myrdal, 1999, pp. 132-135) and indications of it also exist in the study regions historically (Dahlström, 2010; Mats Bunner, herdsman's aid in the 1950's, pers. comm.). Today, fullseason grazing is virtually the only management regime left (Fig. 2).

\subsection{Management intensity}

Disturbance intensity relates to the degree of biomass removal, which is the key factor behind a number of habitat conditions in grasslands, e.g. vegetation height, litter accumulation, gap creation and nutrient removal or reallocation. These habitat conditions in turn largely determine the competition relationships among species (Brys et al., 2005; Elisseou et al., 1995). 


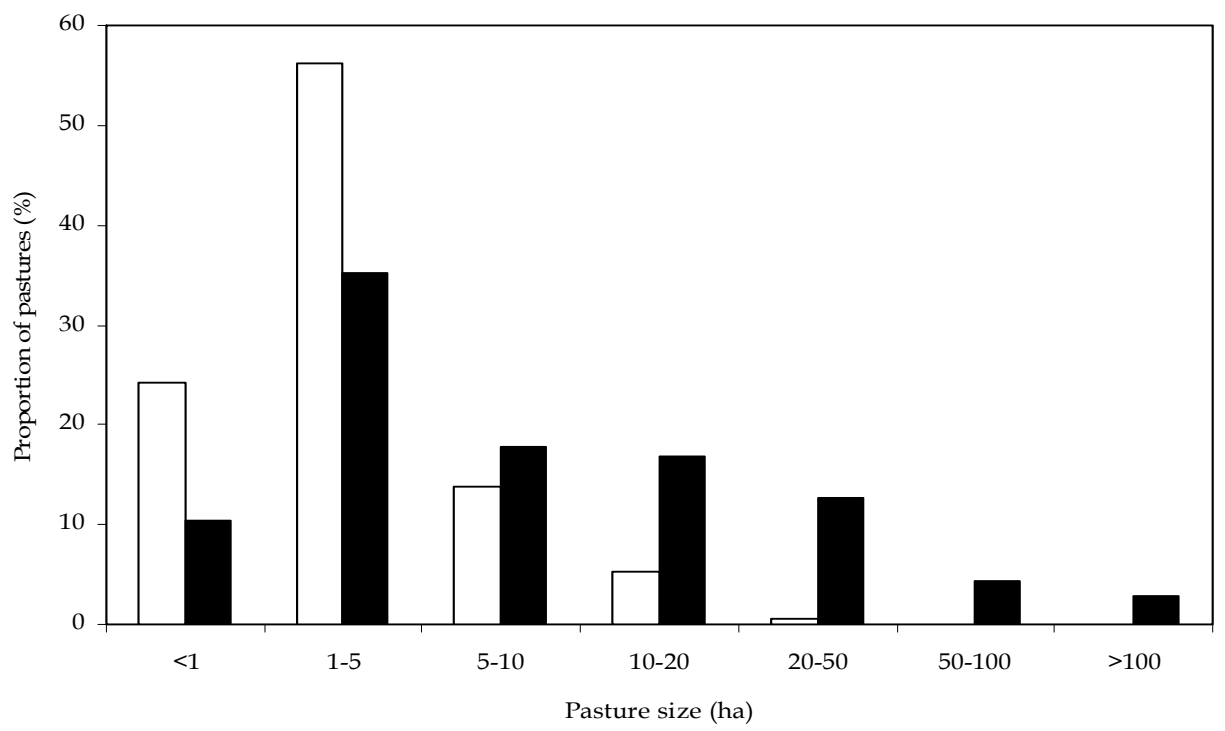

Fig. 3. Proportional size distribution of current (open bars) and $18^{\text {th }}$ century (filled bars) permanent pastures in the study areas

\subsubsection{Ecological significance of disturbance intensity}

In general, disturbance intensity determines several aspects of damage to plant individuals, in turn essential for plant population viability, e.g. risk of being damaged, proportion of the plant removed when damaged, risk of repeated damage and risk of being damaged before completed reproduction (Lennartsson, 2002; Lennartsson \& Oostermeijer, 2001). Seed production of plants decrease with increasing grazing intensity, both because of increased herbivory of reproductive organs (Bühler \& Schmid, 2001; Oostermeijer et al., 2002; Pihlgren, 2007), and because of adverse effects on resistance and tolerance mechanisms (Gatehouse, 2002; Huhta et al., 2000; Huhta et al., 2003). Resistance is affected because intense grazing reduces the selectiveness of the herbivores, thereby reducing benefits of plant traits reducing palatability (Olff \& Ritchie, 1998). Tolerance is affected because mechanisms such as regrowth has limited functionality under repeated damage (Del Val \& Crawley, 2005; Moser \& Schutz, 2006), in particular at sites where plants are stressed, e.g. by drought (Lennartsson, 2000; Oconnor, 1991).

On the other hand, the probability of successful germination and seedling establishment increases with increasing disturbance intensity creating a low vegetation, a thin litter layer and, by means of trampling and grazing, gaps in the litter and vegetation cover (Ehrlén et al., 2005; Fischer \& Matthies, 1998; Kaligaric et al., 2006). Trampling can also "plant" seeds, thereby protecting them from granivory and favouring the germination in some species (Eichberg et al., 2005). Although too high trampling intensity impairs establishment by increasing seedling mortality (Oconnor, 1991; Owens \& Norton, 1992), there is from a disturbance intensity point of view in general a trade-off between seed production and establishment (Pihlgren, 2007; cf. Watt \& Gibson, 1988; Wissman, 2006).

Growth and survival of juvenile and adult plants are also affected by disturbance intensity as a trade-off function. High intensities decrease growth and survival because of increased 
damage frequency (Bühler \& Schmid, 2001), but increases growth and survival of rosettes and low plant stages because of reduced light competition (Lennartsson \& Oostermeijer, 2001; Wallin, 2007).

Grazing, in opposite to mowing, forms a mosaic of shortly grazed and tall ungrazed vegetation patches (Adler et al., 2001; Bakker, 1989; Pratt et al., 1986) due to preferences of the animals towards certain plant species and communities (Huntly, 1991; Jerling \& Andersson, 1982; Putman et al., 1991), avoidance of grazing close to the faeces of conspecifics (Loucougaray et al., 2004; Ritchie \& Olff, 1999) and random grazing behaviour (Brunsell, 2002; Pihlgren, 2007). The proportion of ungrazed patches is important for seed production in the grassland (Pihlgren 2007) and for several groups of invertebrates (e.g. Oostermeijer et al., 2002). High grazing intensity decreases the possibility for grazers to reject patches of vegetation, thereby reducing the described mosaic.

\subsubsection{Management components affecting intensity of disturbance}

In general, estimates of disturbance intensity need to be related to a specific response variable. For example, mowing can be viewed as a more intense disturbance than grazing, because mowing is non-selective, usually non-mosaic and because all harvested biomass is removed, as opposed to grazing, which is selective, causes a mosaic vegetation structure and reallocates nutrients through manure and urine. On the other hand, grazing may be considered more intense than mowing if the risks of early and repeated damage to individual plants are the response variables in focus.

In hay meadows disturbance intensity is not only the result of mowing per se, but is affected also by the two traditional land-use components of raking and burning of debris in spring and aftermath grazing in autumn. Both reduce the litter layer and disturb the ground surface (Carlsson, 1991; Svensson \& Carlsson, 2005; Wallin, 2007; Wissman, 2006) and aftermath grazing in addition implies a repeated, albeit late, damage to plants.

In historical pastures the grazing intensity in a village is difficult to estimate: data on stocking density (grazing area and number of animals) are often available but not data on the pastures' productivity. There are indications of increased grazing intensity over time, e.g. Dahlström (2006a, pp. 132-149) found stocking densities to increase during the period 1620-1850. Moreover, the proportion of individually fenced pastures increased at the cost of common outland pastures, especially in regions directed at crop production and during periods of intense land use. By the $18^{\text {th }}$ century almost all outland was subdivided by fences (Kardell, 2006). This process can be seen as a sign of intensified grassland use, but is also a result of the privatisation of common land (Dahlström, 2006a, pp. 181-203). Some areas reported a shortage of grazing resources until the enclosures of meadows and arable fields in cultivation were opened for grazing in August-September (e.g. some in Kristberg, late 19th century, Dahlström, 2006a, pp. 142-144). In those villages grazing may have been intense in permanent pastures in early but less so in late summer.

Historical stocking densities have been found to differ considerably between villages, thus potentially creating a patchwork of different grazing intensities across the regions (Dahlström, 2006b).

Burning has been used historically in pastures to remove unwanted vegetation, mainly shrubs and dwarf-shrubs but to some extent also old grass (Ekstam \& Forshed, 2000; Moreno \& Villafuerte, 1995; Webb, 1998). Burning can be regarded as increasing the disturbance intensity in pastures, as it contributes to the removal of shrubs and litter. 


\subsubsection{Historical and current management intensity in the study regions}

Stocking densities in $18^{\text {th }}$ century Selaön and present day Östuna are not directly comparable (Fig. 4). However, in both cases stocking densities are generally higher in very small enclosures compared to the larger ones (Fig. 4). Seeing as the median pasture size has decreased by c. $68 \%$, there is an indication of increased stocking densities since the $18^{\text {th }}$ century. If pasture productivity has remained fairly constant, this would imply a higher mean grazing intensity in today's pastures compared with the $18^{\text {th }}$ century.

Based on between-year variation in livestock number, it has been estimated that the average grazing intensity has been equal to consumption of maximum 60 per cent of the biomass in the early 17th century (Dahlström 2006a, pp. 179-180). This is probably less than in current pastures, because subsidiaries for semi-natural pastures are accompanied by a demand to remove most of the biomass annually (Overud \& Lennartsson, 2004).

Although there is no direct evidence of the historical use of spring raking and aftermath grazing in the study regions, both are likely to have occurred, having been commonly applied components of the historical mowing regimes in Sweden (e.g. Lithberg, 1934; Sjörs, 1954, pp. 16-18; von Linné, 1741, August 12th). It is not known if those components occur in the current hay-meadows, but neither is common in meadows in Sweden as a whole (Wallin, 2007). In the regulations for subsidies for hay-meadow management in Sweden, aftermath grazing is not compulsory, but merits extra payment, and spring raking "should be done when needed" (Swedish Board of Agriculture, 2007).

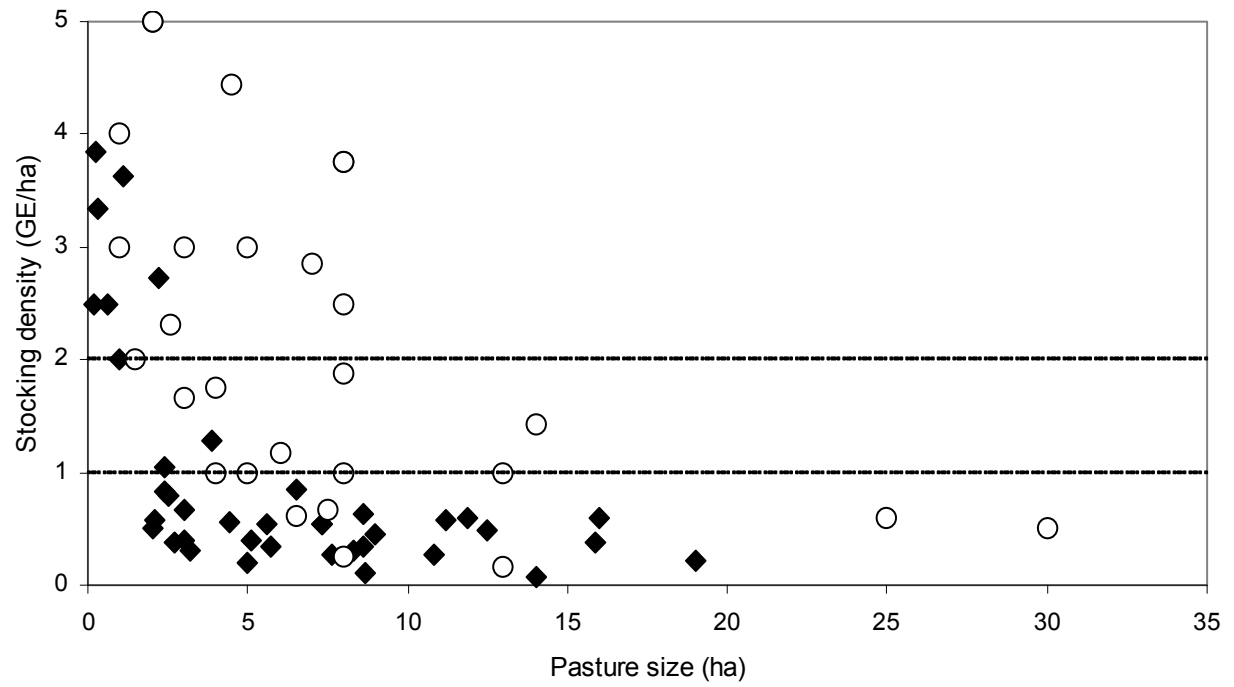

Fig. 4. Eighteenth century stocking densities (grazing equivalents, GE, per hectare) at Selaön $(\diamond)$, and current stocking density in Östuna $(\bigcirc)$. Each data point represents one pasture. The dashed lines indicate current stocking recommendations of non-lactating cows, when pastures are grazed for conservation; mesic pastures above and dry below (HöökPatriksson, 1998) 


\subsection{Dynamics of management}

Dynamics of management is here defined as the between-season variation in timing, intensity and/or type of land-use/management.

\subsubsection{Ecological significance of dynamics of disturbance}

By varying the two components timing and intensity of disturbance the balance in the previously discussed trade-offs can be shifted, namely those between seed production vs. germination (Lennartsson \& Oostermeijer, 2001) and between growth of small, shadesensitive plants and life-stages vs. their survival in very intensively grazed pastures (Helldin \& Lennartsson, 2006). Specifically, in years of late, weak or more selective disturbance the survival of plants as well as the seed production would be favoured, whereas in years of intense disturbance seedling establishment and growth of shade-sensitive plants would instead be favoured. The expected net effect on plant populations should be that variable disturbance intensity gives higher population growth rates than either intense or weak disturbance (cf. Lennartsson \& Oostermeijer, 2001). By changing every-year grazing to every-second-year grazing, seed production increased by 7-14 times and seedling recruitment by 3-4 times (Wissman, 2006). This partly confirms the expected trade-off shift, but indicates also that grasslands are more limited in seed availability than in suitable germination sites (Eriksson \& Ehrlén, 1992; Turnbull et al., 2000). Similarly, a variable grazing intensity may affect the vegetation differently than a constant grazing intensity, even if the mean intensity is equal. For example, in years with intense grazing also unpalatable species, which in the long-run may become dominants, may be grazed and reduced in abundance (Linkowski \& Lennartsson, 2006). Conversely, also palatable species may reproduce in years with weak grazing pressure.

Alternation between grazing and haymaking in two-field systems between years can be expected to create special conditions for grassland plants. The meadow year would favour seed production and growth of good competitors, whereas the pasture year would favour germination, seedling establishment and growth of weak competitors and grazing-resistant species.

Management dynamics also include periods without management. Shorter periods of abandonment, i.e. a few years, affect plants mainly by favouring seed production as well as species and life stages that do not suffer from tall vegetation or increasing litter thickness. During longer periods without management, however, succession processes start, mainly leading to increased abundances of competitive species at the cost of low-competitive ones (Baur et al., 2006; Helldin \& Lennartsson, 2006; Van Andel et al., 1993).

\subsubsection{Management components affecting dynamics of disturbance}

A considerable amount of randomness in the dynamics of disturbance is due to natural variations in a number of grassland habitat parameters. For example, weather conditions affect the timing of mowing between years and cause variations in grassland productivity. In pastures this variation is today counteracted by adjusting the number of livestock (Höök Patriksson, 1998, p. 71). More or less random variations in grazing intensity has been shown for early $17^{\text {th }}$ century, due to considerable variation in local livestock numbers, caused by varying availability of summer fodder during the previous season and winter fodder during the current and also depending on natural demographic fluctuations (Dahlström, 2006a, pp. 96-102; Dahlström, 2006b).

Historically, large variations appear to have existed due to alternating land-use types, including periods without management. For example, Vestbö-Franzén (2004, chapter 7) 
compared $17^{\text {th }}$ century maps of the same villages, but drawn with different levels of detail. Some hay meadows that in one map were drawn as continuous meadow, were in a contemporary map drawn as a patchwork of hay meadows, grazed areas, temporary arable fields and areas of slash-and-burn. This indicates a more flexible use of the meadows than is generally depicted in historical map material, even indicating that parts of the hay meadows were systematically left to succession and then reopened after a period of abandonment (Vestbö-Franzén, 2004). This is consistent with Sjöbecks (1933) description of the early 20th century use of wooded hay meadows in south Sweden.

More regular dynamics, indicated in many maps, is created for example by the rhythm of grazing in the widespread two-field system (Ekstam \& Forshed, 1996). The majority of a property's arable fields were divided into two areas, each enclosed by a fence and each comprising one year's worth of crop production. Each enclosure was used for crop production every second year; the one in fallow was instead used for grazing (Gadd, 2000, p. 115). A varying amount of pasture could also be enclosed with the arable fields and were thus in a two-year land-use rhythm. Hay meadows included in the two-field rhythm were common in the region around Källstorp/Söne (Jansson, 1998, p. 121). They were treated as hay meadow during the year in cultivation (spring raking, mowing and aftermath grazing) and as pasture (full-season grazing) during the year in fallow. Herding within the arable field enclosures was common in the lowlands (Kardell, 2006), thus in some cases counteracting the described two-year rhythms of haymaking and grazing.

\subsubsection{Historical and current management dynamics in the study regions}

Historically, about $3 \%$ of the grassland area was located in two-field enclosures, indicating that grazing and, to a small extent, mowing were subject to a two-year rhythm (Fig. 2). Three variants of such land-use regimes were identified for the study regions historically (Fig. 2). Today, there is no systematically dynamic management regime in the study area. Pastures being smaller today than in the $18^{\text {th }}$ century (Fig. 3) imply that the variation at the patch level between years is smaller, especially because it is likely that grazing intensity is higher today. The variation in grassland productivity today is, to a larger extent than historically, counteracted by varying the stocking densities or by mechanical trimming of ungrazed patches of vegetation (Overud \& Lennartsson, 2004). The trimming ensures that the farmer fulfils the management goal of the vegetation being "well grazed", thereby avoiding sanctions (Swedish Board of Agriculture, 2007).

Today there are many abandoned grasslands that are in succession at a stage corresponding to the historical abandonment periods (Sjöbeck, 1933; Vestbö-Franzén, 2004). Today the process of succession is rarely broken by restoration (Swedish University of Agricultural Sciences, 2010). Recently the Swedish regulations for environmental subsidies introduced the possibility of one grazing free year out of five (Swedish Board of Agriculture, 2007), which opens up for the possibility of introducing a certain amount of short-term variation. There is as yet no national statistics on how widely it is applied (Swedish Board of Agriculture, pers. comm.). Longer periods of abandonment or shorter intervals between grazing free years are not liable for environmental subsidies.

\section{Discussion}

This study confirms the loss of area of semi-natural grassland described from other parts of Scandinavia and Europe. It furthermore indicates a loss of habitat quality. The pre-industrial agricultural systems contained a range of land-use regimes and components many of which 
are absent or rare today: the large overall abundance and distribution of grassland during hundreds of years (e.g. Eriksson et al., 2002), the presence of many different grassland types in every agricultural landscape, the presence of land-use types which form disturbance regimes that are particularly beneficial for biodiversity (this study), the long continuity of specific land-use types and combinations of types within single grasslands (Fischer \& Wipf, 2002; Gustavsson et al., 2007), and the dynamic land-use regimes (this study; Dahlström, 2006a,b; Sjöbeck, 1933; Vestbö-Franzén, 2004). Several of these components can be expected to be ecologically necessary, as they provided ecological conditions necessary for grassland biodiversity. Such change of habitat conditions may well explain the reported cases of decline of grassland biodiversity in semi-natural grassland subject to conservation management.

Timing of management has changed, in particular in terms of loss of late disturbance. Today, most of the remaining grasslands are managed with grazing during the entire season irrespective of historical land-use regime. The loss is caused by loss of mowing and of late grazing in pastures fenced with meadow or arable field; both losses imply a loss of late disturbance at the enclosure level. In addition, drastically decreased median pasture size and indications of increased stocking densities imply an earlier mean disturbance at the patch level because the vegetation is grazed faster.

As indicated by the literature review performed in this study, as well as by several empirical studies, the loss of late managed grassland can be expected to have large effects on grassland biodiversity (Linusson et al., 1998; Matijková et al., 2003; Mitlacher et al., 2002). Plants are affected mainly through reduced flowering and seed production, but increased probability of a seed establishing a new plant, especially in small and low-competitive species (Jutila, 2003; Jutila \& Grace, 2002; Lennartsson \& Oostermeijer, 2001). Empirical studies have suggested that the recruitment of grassland plants is limited rather by seed production than by germination sites (Eriksson \& Ehrlén, 1992; Turnbull et al., 2000; Wissman, 2006). Empirical studies have also demonstrated increasing densities of plant individuals in the sward when late disturbance was introduced (Wissman, 2006), and an increased content of forbs in the vegetation (Pavlů et al., 2006).

Early-flowering plant species, which have historically been favoured by late management, can be expected to be particularly negatively affected by the loss of late disturbance. This is the case also for early-flowering ecotypes which may have been evolved in man-made habitats along with the use of mowing and other late grassland use (Karlsson, 1984; Lennartsson, 1997 and references therein).

Subsequently, the effects of management timing on plants strongly affect a number of grassland invertebrate groups, in particular phytophagous, nectar- and pollen feeding insects (Kruess \& Tscharntke, 2002; Söderström et al., 2001). Reduced pollen- and nectar resources have been suggested to be an important threat to, for example, wild bees, of which several species are red listed (Linkowski et al., 2004; Pekkarinen, 1998; Pekkarinen, 1999). For phytophagous insects, timing of disturbance to their host plant is crucial, especially for sedentary larvae that are killed when the plant is eaten or cut (Johst et al., 2006; Valtonen \& Saarinen, 2005). Moreover, different groups of ground-dwelling, predatory arthropods are favoured by either early or late onset of grazing due to the differences in vegetation structure (Lenoir \& Lennartsson, 2010).

Intensity of management appears to have increased from the $18^{\text {th }}$ century until today due to earlier management in pastures and hay-meadows, smaller pastures, and probably increased stocking densities. In the remaining hay-meadows, however, some changes of 
management, namely reduced use of spring raking and aftermath grazing, may however have reduced the intensity. Although current grazing intensity probably is higher than the historical, it is sometimes argued that management intensity at the landscape level has decreased because of large areas of abandoned grasslands (cf. Helldin \& Lennartsson, 2006). This may be true during a succession phase, but in the long run too weak management (or none) in some grasslands cannot compensate for too intense management in others.

Some ecological effects of intensification of management are similar to the effects of managing grasslands earlier, such as reduced probability of finishing reproduction before disturbance, reduced resources of pollen, nectar, and host-plants for invertebrates, better conditions for shade-sensitive species of plants and invertebrates which occur close to the ground. Intensification of grazing also increases mortality of plants induced by trampling and repeated grazing, reduces the selectivity and patchiness of grazing, and reduces the litter layer. All these effects can be expected to change the species composition of grassland plants and invertebrates, and to threaten certain species.

Dynamics of management has decreased considerably in terms of between-year variation of timing, intensity, and type of management. Some of the historical long-term grassland dynamics, long enough for succession processes to start, can be said to be temporarily imitated by the currently abandoned successional habitats. The loss of dynamics can be expected to change the habitat conditions in single grasslands because sequences of different land use are replaced by more uniform management, and to decrease the variation between grasslands because the uniformity applies to most grasslands in a landscape.

Pre-industrial grassland use provided both predictable dynamics in the form of sequences of different land-use regimes and unpredictable variation in the form of, for example, varying number of livestock combined with between-year variations in productivity. One obvious ecological effect of this is that historical land use formed a mosaic landscape; although conditions could be less favourable for a grassland species in a certain place or at a certain time, more benign conditions were seldom far away, in space or in time. For mobile organisms like insects, dynamic management implies that suitable vegetation structures are always available (e.g. Brown, 1984; Cameron \& Bryant, 1999). The review in this study indicates that between-year variation in grassland management can also favour plant diversity in a single grassland, through favouring of some life-stages one year and other stages the next year.

\subsection{Implications for conservation of grassland biodiversity}

Acknowledging the past and ongoing loss of semi-natural grassland ecosystems, the European Common Agricultural Policy (CAP) aims at increasing the area of semi-natural grassland by awarding environmental subsidies for management and restoration (Swedish Board of Agriculture, 2007). Although the area of semi-natural grassland is thus given high priority in the CAP, the subsidiary systems also contain regulations in order to obtain sufficient ecological quality in the remaining grasslands. For example, an awareness of the differences between grassland types in terms of threats, values and management requirements has motivated different national schemes for the application of the CAP.

An important question is, however, whether the quality aspect of grassland management is enough acknowledged and implemented in grassland conservation within the CAP and in other conservation efforts, such as national protection of nature. For example, the Swedish application of the CAP has been criticized for intensifying and homogenising grassland 
management through being concerned mainly with regulations for keeping the litter layer thin, producing a short grass sward, and minimising shrub cover (Höök-Patriksson, 1998; Overud \& Lennartsson, 2004), and through excluding several ecologically important and historically widespread grassland types and management components (Andersson \& Paltto, 2008).

Based on this study, we make some suggestions for future conservation of grassland biodiversity:

Always question whether management for conservation in a particular grassland is ecologically similar enough to the historical land use to be considered "continued" or "resumed" management and thus whether the management can be expected to preserve the grassland's biodiversity. Some of the habitats discussed in this study have experienced such a profound shift of disturbance regime that they should probably be considered new habitats; examples are hay-meadows and late grazed pastures, now managed with full-season grazing every summer. Such grasslands should in many cases probably be disregarded in area estimates of semi-natural grassland that aim at estimating functional, or effective, area of grassland, analogous to, for example, effective population size.

1. Apply and develop further the interdisciplinary approach employed in this study, in which detailed ecological and historical knowledge are combined in order to identify which ecological variables that are most crucial for grassland species, both in general and for the current species composition in specific grasslands, and what historical landuse components that created these factors. Grassland ecology and land use can preferably be interpreted in terms of type, timing, intensity, and dynamics of disturbance, as in this study, but also other aspects of the grassland ecology may be important in certain grassland habitats, such as temporary cultivation and the use of trees and shrubs. In this study vascular plants were used as target organism group, but in order to preserve the entire grassland biodiversity it is important to perform similar studies also for other groups.

2. Apply knowledge-based, adaptive grassland management from the identified links between species, habitat and components of the historical disturbance regimes. Several studies of plant population viability and plant diversity have indicated the benefits of local, traditional management compared to new or modified methods of grassland management (Fischer \& Wipf, 2002; Hansson \& Fogelfors, 2000; Köhler et al., 2005; Maurer et al., 2006). Restoring habitat quality by reintroducing the place-specific historical regime is however not always possible. For example, manual mowing is often too labour intensive, and all the land-use variations that existed in the pre-industrial landscape cannot be introduced into the small habitat fragments managed today. Instead, some missing ecological variables must be created by applying novel management methods, i.e. ecological engineering, thus functionally mimicking the historical land-use components (Lennartsson, 2003; Lennartsson \& Linkowski, 2011). Non-historical management has in some cases been shown to function equally well as historical from a biodiversity point of view (e.g. Ruzickova et al., 2001), such as historical mowing being replaced by late onset of grazing (Wissman 2006).

3. Identify and prioritise in the CAP such regions in which traditional land use is still practiced and in which the grassland ecosystems can thus be expected to be ecologically functional. One of the most striking examples is the Romanian Carpathians which contains the largest areas of traditionally mown hay-meadows in Europe (Lennartsson \& Helldin, 2007). It is essential that the CAP regulations are not resulting in 
deterioration of the land-use methods in such regions, but instead are designed based on the knowledge of grassland ecology that can be derived from these land-use systems.

\section{Conclusions}

In conclusion, in the pre-industrial agricultural landscape, suboptimal management in some grasslands and during some time periods was probably not a problem because the vast grassland areas created a variety of management regimes and could support viable metapopulations of grassland species. In the current landscape, few species exhibit functioning metapopulations, hence restoration and management measures need to ensure sufficient habitat quality more or less in each single grassland. We therefore urge for knowledge-based management for conservation and regulation of environmental subsidies. This study indicates the need to focus on restoration of grassland quality. It also shows that more multi-disciplinary research is needed that combines historical, ecological and agricultural knowledge. Although restoration of habitat quality should thus be based on ecological-historical analyses of the grassland habitats and their species, the restoration methods may well be based on novel tools as long as the new methods provide all necessary ecological variables. Seeing as grasslands owe their species richness to past land-use practices, studying the components of historical land use in greater detail and in an ecological context may reveal not only new details of grassland ecology as such. It may also contribute to significant knowledge also of the ecology of the agricultural landscape in general, thereby providing keys as to the development of new conservation tools and strategies.

\section{Acknowledgement}

This study was funded by The Bank of Sweden Tercentenary Foundation and The Royal Academy of Letters, History and Antiquities through Nordiska Museet Research School, The Foundation for Strategic Environmental Research (HagmarksMISTRA), the Swedish Council for Forestry and Agricultural Research (award 34.0297/98 to T. Lennartsson) and the Swedish National Heritage Board (Biocultural Heritage).

\section{References}

Adler, P.B., Raff, D.A. \& Lauenroth, W.K. (2001). The effect of grazing on the spatial heterogeneity of vegetation. Oecologia, Vol. 128, pp. 465-479

Andersson, L. \& Paltto, H. (2008), Hur har natur- och kulturvärden påverkats av röjning/avverkning i betesmarker?, Pro Natura. http:/ / www.pro-natura.net/Rapport\%20-\%20uppf\%F6ljning\%20av\%2050tr\%E4dsregeln\%20-\%20slutversion.pdf

Arrhenius, J. \& Lindquist, C. A. (1904). Lantbrukspraktika Beijers Bokförlags-Aktiebolag, Stockholm.

Aurell, J. J. Söne socken, storskifte. [16-SÖN-1g]. 1787. Mariestad, Cadastral map, Swedish Land Survey Agency.

Bailey, D. W., Dumont, B., \& WallisDeVries, M. F. (1998). Utilization of heterogeneous grasslands by domestic herbivores: Theory to management. Annales de Zootechnie, Vol 47, pp. 321-333. 
Baillie, J. E. M. (2004). 2004 IUCN Red List of Threatened Species: A Global Species Assessment International Union for the Conservation of Nature, 2831708265.

Bakker, J. P. (1989). Nature management by grazing and cutting. On the ecological significance of grazing and cutting regimes applied to restore former species-rich grassland communities in the Netherlands. Kluwer Academic Press, 0792300688, Dordrecht, Netherlands.

Baur, B., Cremene, C., Groza, G., Rakosy, L., Schileyko, A. A., Baur, A., Stoll, P., \& Erhardt, A. (2006). Effects of abandonment of subalpine hay meadows on plant and invertebrate diversity in Transylvania, Romania. Biological Conservation, Vol. 132, pp. 261-273.

Bernes, C. (1993). The Nordic Environment - Present State, Trends and Threats. The Nordic Council of Ministers, Stockholm.

Boschi, C. \& Baur, B. (2007). Effects of management intensity on land snails in Swiss nutrient-poor pastures. Agriculture Ecosystems \& Environment, Vol. 120, pp. 243-249.

Brown, V. K. (1984). Secondary succession: Insect-plant relationships. BioScience 34, 710-716.

Brunsell, M. (2002), Betesrator och kärlväxters reproduktion - En studie av naturbetesmarkers heterogenitet $i$ tid och rum. (Grazing rejects and the reproduction of vascular plants - A study on the spatial and temporal heterogeneity in semi-natural grasslands, in Swedish), Department of Conservation Biology, Swedish University of Agricultural Sciences, Uppsala, 79.

Bruun, H. H., Fritzbøger, B., Rindel, P. O., \& Hansen, U. L. (2001). Plant species richness in grasslands: the relative importance of contemporary environment and land-use history since the Iron Age. Ecography, Vol. 24, pp. 569-578.

Brys, R., Jacquemyn, H., Endels, P., De Blust, G., \& Hermy, M. (2004). The effects of grassland management on plant performance and demography in the perennial herb Primula veris. Journal of Applied Ecology, Vol. 41, pp. 1080-1091.

Brys, R., Jacquemyn, H., Endels, P., De Blust, G., \& Hermy, M. (2005). Effect of habitat deterioration on population dynamics and extinction risks in a previously common perennial. Conservation Biology, Vol. 19, pp. 1633-1643.

Bühler, C. \& Schmid, B. (2001). The influence of management regime and altitude on the population structure of Succisa pratensis: implications for vegetation monitoring. Journal of Applied Ecology, Vol. 38, pp. 689-698.

Cameron, G. N. \& Bryant, E. H. (1999). Species composition and trophic structure of insect communities in Texas prairies. Prairie Naturalist, Vol. 31, pp. 221-242.

Carlsson, A. (1991). Kransrams - västsvensk fagningsblomma. Svensk botanisk tidskrift, Vol. 85, p. 81.

Cheffings, C. M. \& Farrel, L. (2005). The Vascular Plant Red Data List for Great Britain - Species Status No 7 Joint Nature Conservation Committee, 2831708265.

Dahlström, A. (2006a). Betesmarker, djurantal och betestryck 1620-1850. Naturvårdsaspekter på historisk beteshävd $i$ Syd-och Mellansverige. (Pastures, livestock number and grazing pressure 1620-1850. Ecological aspects of grazing history in south-central Sweden. In Swedish with English summary) Swedish Biodiversity Centre, Uppsala.

Dahlström, A. (2006b). Grazing dynamics at different spatial and temporal scales: examples from the Swedish historical record a.d. 1620-1850. Vegetation History and Archaeobotany, Online First, DOI 10.1007/s00334-006-0087-1.

Dahlström, A. (2010). Markanvändningsdynamik - rekonstruktion med hjälp av bondedagböcker och historiska kartor. In Nycklar till kunskap. Om människans bruk av naturen. eds. H. Tunón \& A. Dahlström, Centrum för biologisk mångfald, Uppsala \& Kungl. Skogs- och lantbruksakademien, Stockholm. 
Dahlström, A., Lennartsson, T., Wissman, J., \& Frycklund, I. (2008). Biodiversity and traditional land use in south-central Sweden - the significance of timing of management. Environment and History, Vol. 14, pp. 385-403.

Del Val, E. K. \& Crawley, M. J. (2005). Are grazing increaser species better tolerators than decreasers? An experimental assessment of defoliation tolerance in eight British grassland species. Journal of Ecology, Vol. 93, pp. 1005-1016.

Ehrlén, J., Syrjänen, K., Leimu, R., Garcia, M. B., \& Lehtilä, K. (2005). Land use and population growth of Primula veris: an experimental demographic approach. Journal of Applied Ecology, Vol. 42, pp. 317-326.

Eichberg, C., Storm, C., \& Schwabe, A. (2005). Epizoochorous and post-dispersal processes in a rare plant species: Jurinea cyanoides (L.) Rchb. (Asteraceae). Flora, Vol. 200, pp. 477-489.

Ekstam, U. \& Forshed, N. (1996). Äldre fodermarker. Betydelsen av hävdregimen i det förgångna. Målstyrning. Mätning och uppföljning. Naturvårdsverkets förlag, 91-620-1147-2, Stockholm.

Ekstam, U. \& Forshed, N. (2000). Svenska Naturbetesmarker, historia och ekologi. Naturvårdsverkets förlag, 91-620-1202-9, Stockholm.

Elisseou, G. C., Veresoglou, D. S., \& Mamolos, A. P. (1995). Vegetation productivity and diversity of acid grasslands in Northern Greece as influenced by winter rainfall and limiting nutrients. Acta Oecologica-International Journal of Ecology, Vol. 16, pp. 687702.

Emanuelsson, U. (1988). A model describing the development of the agricultural landscape. In The Cultural Landscape - Past, Present and Future, eds. H. H. Birks et al., pp. 111122. Cambridge University Press, Bergen.

Eriksson, O., Cousins, S. A. O., \& Bruun, H. H. (2002). Land-use history and fragmentation of traditionally managed grasslands in Scandinavia. Journal of Vegetation Science, Vol. 13, pp. 743-748.

Eriksson, O. \& Ehrlén, J. (1992). Seed and Microsite Limitation of Recruitment in PlantPopulations. Oecologia, Vol. 91, pp. 360-364.

European Union. (2011). Common Agricultural Policy (CAP) in the European Union, 3-18-2011, Available from http://ec.europa.eu/agriculture/capreform/index_en.htm

Fischer, M. \& Matthies, D. (1998). Experimental demography of the rare Gentianella germanica: seed bank formation and microsite effects on seedling establishment. Ecography, Vol. 21, pp. 269-278.

Fischer, M. \& Wipf, S. (2002). Effect of low-intensity grazing on the species-rich vegetation of traditionally mown subalpine meadows. Biological Conservation, Vol. 104, pp. 1-11.

Gadd, C.-J. (2000). Den agrara revolutionen. 1700-1870. Natur och Kultur/LTs förlag, 91-2735222-6.

Gärdenfors, U. (2010). Rödlistade arter i Sverige 2010 - The 2010 redlist of Swedish species ArtDatabanken, 978-91-88506-35-1, Uppsala.

Gatehouse, J. A. (2002). Plant resistance towards insect herbivores: a dynamic interaction. New Phytologist, Vol. 156, pp. 145-169.

Grigg, D. B. (1974). The agricultural systems of the world: an evolutionary approach Cambridge U.P., London.

Gustavsson, E., Lennartsson, T., \& Emanuelsson, M. (2007). Land use more than 200 years ago explains current grassland plant diversity in a Swedish agricultural landscape. Biological Conservation, Vol. 138, pp. 47-59. 
Hansson, M. \& Fogelfors, H. (2000). Management of a semi-natural grassland; results from a 15-year-old experiment in southern Sweden. Journal of Vegetation Science, Vol. 11, pp. 31-38.

Helldin, J.-O. \& Lennartsson, T. (2006). Lagom är bäst - ett måttligt betestryck ger den största mångfalden (A moderate grazing pressure favours the greatest range of biodiversity, in Swedish). Biodiverse, Vol. 4, pp. 17-19.

Hierpe, C. Källstorps säteri, geometrisk avmätning. [P266-6:1]. 1712. Gävle, Swedish Land Survey Agency. Ref Type: Map

Höök Patriksson, K. (1998). Skötselhandbok för gårdens natur- och kulturvärden. Swedish Board of Agriculture, 9188264-20-3, Jönköping.

Huhta, A. P., Hellström, K., Rautio, P., \& Tuomi, J. (2003). Grazing tolerance of Gentianella amarella and other monocarpic herbs: why is tolerance highest at low damage levels? Plant Ecology, Vol. 166, pp. 49-61.

Huhta, A. P., Lennartsson, T., Tuomi, J., Rautio, P., \& Laine, K. (2000). Tolerance of Gentianella campestris in relation to damage intensity: an interplay between apical dominance and herbivory. Evolutionary Ecology, Vol. 14, pp. 373-392.

Huntly, N. (1991). Herbivores and the dynamics of communities and ecosystems. Annual Review of Ecology and Systematics, Vol. 22, pp. 477-503.

Israelsson, C. (2005). Kor och människor. Nötkreatursskötsel och besättningsstorlekar på torp och herrgårdar 1850-1914, Doctoral thesis, Department of Economics, Section of Agricultural History, Swedish University of Agricultural Sciences, Uppsala.

Jansson, U. (1998). Odlingssystem $i$ Vänerområdet. En studie av tidigmodernt jordbruk $i$ Västsverige., Meddelanden Nr 103, Kulturgeografiska institutionen, Stockholms universitet.

Jantunen, J., Saarinen, K., Valtonen, A., \& Saarnio, S. (2007). Flowering and seed production success along roads with different mowing regimes. Applied Vegetation Science, Vol. 10, pp. 285-292.

Jerling, L. \& Andersson, M. (1982). Effects of selective grazing by cattle on the reproduction of Plantago maritima. Holarctic Ecology, Vol. 5, pp. 405-411.

Johst, K., Drechsler, M., Thomas, J., \& Settele, J. (2006). Influence of mowing on the persistence of two endangered large blue butterfly species. Journal of Applied Ecology, Vol. 43, pp. 333-342.

Jutila, H. M. (2003). Germination in Baltic coastal wetland meadows: similarities and differences between vegetation and seed bank. Plant Ecology, Vol. 166, pp. 275-293.

Jutila, H. M. \& Grace, J. B. (2002). Effects of disturbance on germination and seedling establishment in a coastal prairie grassland: a test of the competitive release hypothesis. Journal of Ecology, Vol. 90, pp. 291-302.

Kain, R. J. P. \& Baigent, E. (1992). The cadastral map in the service of the state: a history of property mapping The University of Chicago Press, London.

Kaligaric, M., Skornik, S., Ivancic, A., Rebeusek, F., Sternberg, M., Kramberger, B., \& Sencic, L. (2006). Germination and survival of endangered Pulsatilla grandis (ranunculaceae) after artificial seeding, as affected by various disturbances. Israel Journal of Plant Sciences, Vol. 54, pp. 9-17.

Kardell, Ö. (2006). Vallning, bete, mjölkning och hägnader kring sekelskiftet 1900: en kontextuell skiss. Svenska Landsmål och Svenskt Folkliv B 129, 49-77.

Karlsson, T. (1984). Early-flowering taxa of Euphrasia (Scrophulariaceae) on Gotland, Sweden. Nordic Journal of Botany, Vol. 4, pp. 303-326. 
Kleijn, D. \& Sutherland, W. J. (2003). How effective are European agri-environment schemes in conserving and promoting biodiversity? Journal of Applied Ecology, Vol. 40, pp. 947-969.

Köhler, B., Gigon, A., Edwards, P. J., Krüsi, B., Langenauer, R., Lüscher, A., \& Ryser, P. (2005). Changes in the species composition and conservation value of limestone grasslands in Northern Switzerland after 22 years of contrasting managements. Perspectives in Plant Ecology Evolution and Systematics, Vol. 7, pp. 51-67.

Kruess, A. \& Tscharntke, T. (2002). Grazing intensity and the diversity of grasshoppers, butterflies, and trap-nesting bees and wasps. Conservation Biology, Vol. 16, pp. 15701580.

Lanta, V., Dolezal, J., Lantova, P., Kelisek, J., \& Mudrak, O. (2009). Effects of pasture management and fertilizer regimes on botanical changes in species-rich mountain calcareous grassland in Central Europe. Grass and Forage Science, Vol. 64, pp. 443453.

Lennartsson, T. (1997). Demography, reproductive biology and adaptive traits in Gentianella campestris and G. amarella. - Evaluating grassland management for conservation by using indicator plant species, Doctoral thesis, Acta Universitatis Agriculturae Suecicae Agraria 46.

Lennartsson, T. (2000). Management and population viability of the pasture plant Gentianella campestris: the role of interactions between habitat factors. Ecological Bulletines, Vol. 48, pp. 111-121.

Lennartsson, T. (2002). Extinction thresholds and disrupted plant-pollinator interactions in fragmented plant populations. Ecology, Vol. 83, pp. 3060-3072.

Lennartsson, T. (2003). Vilken traditionell kunskap är relevant för naturvården? - några svar från fältgentianans horisont. (Which traditional knowledge is relevant in conservation? - some answers from the horizon of the field gentian, in Swedish). Biodiverse 8, 7 .

Lennartsson, T. \& Helldin, J.-O. (2007). Agricultural landscapes in Eastern Europe as reference areas for Swedish land management. Kungl.Skogs- och Lantbruksakademiens tidskrift, Vol. 5, pp. 26-30.

Lennartsson, T. \& Linkowski, W. Markanvändningshistoria och biologisk mångfald. Almstedt, M. and Ebenhard, T. Naturvårdskedjans avnämarbok . 2011. Uppsala, Swedish Biodiversity Centre. Ref Type: In Press

Lennartsson, T., Nilsson, P., \& Tuomi, J. (1998). Induction of overcompensation in the field gentian, Gentianella campestris. Ecology, Vol. 79, pp. 1061-1072.

Lennartsson, T. \& Oostermeijer, J. G. B. (2001). Demographic variation and population viability in Gentianella campestris: effects of grassland management and environmental stochasticity. Journal of Ecology, Vol. 89, pp. 451-463.

Lennartsson, T., Tuomi, J., \& Nilsson, P. (1997). Evidence for an evolutionary history of overcompensation in the grassland biennial Gentianella campestris (Gentianaceae). American Naturalist, Vol. 149, pp. 1147-1155.

Lenoir, L. 1. 1. s. s. \& Lennartsson, T. (2010). Effects of timing of grazing on arthropod communities in semi-natural grasslands. Journal of Insect Science (Tucson), Vol. 10.

Linkowski, W., Cederberg, B., \& Nilsson, L. A. (2004). Vildbin och fragmentering Swedish Board of Agriculture, Jönköping.

Linkowski, W. \& Lennartsson, T. (2006), Renbete och biologisk mångfald. Kunskapssammanställning. (Biodiversity in subalpine birch forest. Literature review. In Swedish.), Länsstyrelsen i Norrbottens län, 18/2006. 
Linusson, A.-C., Berlin, G. A. I., \& Olsson, E. G. A. (1998). Reduced community diversity in semi-natural meadows in southern Sweden, 1965-1990. Plant Ecology, Vol. 136, pp. 77-94.

Lithberg, N. (1934). Gotlandsängen. Sveriges Naturskyddsförenings årsskrift, pp. 92-102.

Loucougaray, G., Bonis, A., \& Bouzillé, J.-B. (2004). Effects of grazing by horses and/or cattle on the diversity of coastal grasslands in western France. Biological Conservation, Vol. 116, pp. 59-71.

Matijková, I., van Diggelen, R., \& Prach, K. (2003). An attempt to restore a central European species-rich mountain grassland through grazing. Applied Vegetation Science, Vol. 6, pp. 161-168.

Maurer, K., Weyand, A., Fischer, M., \& Stocklin, J. (2006). Old cultural traditions, in addition to land use and topography, are shaping plant diversity of grasslands in the Alps. Biological Conservation, Vol. 130, pp. 438-446.

Mitlacher, K., Poschlod, P., Rosén, E., \& Bakker, J. P. (2002). Restoration of wooded meadows - a comparative analysis along a chronosequence on Öland (Sweden). Applied Vegetation Science, Vol. 5, pp. 63-73.

Moreno, S. \& Villafuerte, R. (1995). Traditional Management of Scrubland for the Conservation of Rabbits Oryctolagus-Cuniculus and Their Predators in DonanaNational-Park, Spain. Biological Conservation, Vol. 73, pp. 81-85.

Moser, B. \& Schutz, M. (2006). Tolerance of understory plants subject to herbivory by roe deer. Oikos, Vol. 114, pp. 311-321.

Myrdal, J. (1999). Jordbruket under feodalismen. 1000-1700 Natur och Kultur/LTs Förlag, 91-2735221-8, Stockholm.

Myrdal, J. (2001), Den nya produktionen - det nya uppdraget: jordbrukets framtid i ett historiskt perspektiv, Jordbruksdepartementet, Regeringskansliet, Stockholm, 2001:68.

National Atlas of Sweden (1995). Climate, lakes and rivers. SNA Publ., Stockholm.

Öckinger, E., Eriksson, A. K., \& Smith, H. G. (2006). Effects of grassland abandonment, restoration and management on butterflies and vascular plants. Biological Conservation, Vol. 133, pp. 291-300.

Oconnor, T. G. (1991). Local Extinction in Perennial Grasslands - A Life-History Approach. American Naturalist, Vol. 137, pp. 753-773.

Ohlsson, E. W. (2006). Det gotländska änget Ödin, Visby.

Olff, H. \& Ritchie, M. E. (1998). Effects of herbivores on grassland plant diversity. Trends in Ecology \& Evolution, Vol. 13, pp. 261-265.

Oostermeijer, J. G. B., Luijten, S. H., Ellis-Adam, A. C., \& den Nijs, J. C. M. (2002). Future prospects for the rare, late-flowering Gentianella germanica and Gentianopsis ciliata in Dutch nutrient-poor calcareous grasslands. Biological Conservation, Vol. 104, pp. 339-350.

Overud, S. \& Lennartsson, T. (2004), Skötsel och restaurering av betesmarker och slåtterängar. En sammanställning av den regionala naturvårdens kunskaper och erfarenheter. (Management and restoration of seminatural grasslands. A review of practical conservation knowledge. In Swedish)., Swedish Board of Agriculture, Swedish Environmental Protection Agency, The National Heritage Board, Stockholm, No. 2004:11.

Owens, M. K. \& Norton, B. E. (1992). Interactions of Grazing and Plant-Protection on Basin Big Sagebrush (Artemisia-Tridentata Ssp Tridentata) Seedling Survival. Journal of Range Management, Vol. 45, pp. 257-262.

Pavlů, V., Hejcman, M., Pavlů, L., Gaisler, J., Nežerková, P., \& Meneses, L. (2006). Changes in plant densities in a mesic species-rich grassland after imposing different grazing management treatments. Grass and Forage Science, Vol. 61, pp. 42-51. 
Pekkarinen, A. (1998). Oligolectic bee species in Northern Europe (Hymenoptera, Apoidea). Entomologica Fennica, Vol. 8, pp. 205-214.

Pekkarinen, A. Oligolectic bee species and their decline in Finland (Hymenoptera: Apoidea). Proceedings of the XXIV Nordic Congress of Entomology, 151-156. 1999. Conference Proceeding

Piessens, K. \& Hermy, M. (2006). Does the heathland flora in north-western Belgium show an extinction debt? Biological Conservation, Vol. 132, pp. 382-394.

Pihlgren, A. (2007). Small-Scale Structures and Grazing Intensity in Semi-Natural Pastures, Doctoral thesis, Acta Universitatis Agriculturae Sueciae, No. 2007:13.

Plantureux, S. (1996). Biodiversity, type of soil and management intensity of permanent pastures of Plateau Lorrain. Acta Botanica Gallica, Vol. 143, pp. 339-348.

Pratt, R. M., Putman, R. J., Ekins, J. R., \& Edwards, P. J. (1986). Use of habitat by free-ranging cattle and ponies in the New Forest, Southern England. Journal of Applied Ecology, Vol. 23, pp. 539-557.

Putman, R. J., Fowler, A. D., \& Tout, S. (1991). Patterns of use of ancient grassland by cattle and horses and effects on vegetational composition and structure. Biological Conservation, Vol. 56, pp. 329-347.

Pykälä, J. (2000). Mitigating human effects on European biodiversity through traditional animal husbandry. Conservation Biology, Vol. 14, pp. 705-712.

Reitalu, T., Johansson, L. J., Sykes, M. T., Hall, K., \& Prentice, H. C. (2010). History matters: village distances, grazing and grassland species diversity. Journal of Applied Ecology, Vol. 47, pp. 1216-1224.

Riddersporre, M. (1995). Village Lands in the Rear-view Mirror: the Cultivated Landscape Before the Age of the Maps, Doctoral thesis, Department of Geography, Lund University.

Ritchie, M. E. \& Olff, H. (1999). Herbivore diversity and plant dynamics: compensatory and additive effects. In Herbivores: Between Plants and Predators. The 38th Symposium of the British Ecological Society, eds. H. Olff, V. K. Brown, \& R. H. Drent, pp. 175-204. Blackwell Science, Oxford, UK.

Rosenthal, J. P. \& Kotanen, P. (1994). Terrestrial plant tolerance to herbivory. Trends in Ecology \& Evolution, Vol. 9, pp. 145-148.

Ruzickova, H., Halada, L., David, S., \& Gerhatova, K. (2001). Management of meadows in the Biosphere Reserve East Carpathians. II. Results after 7 years. Ekologia-Bratislava, Vol. 20, pp. 76-87.

Simán, S. \& Lennartsson, T. (1998). Slåtter eller bete i naturliga fodermarker? - ett skötselförsök med slåtteranpassade växter. Svensk botanisk tidskrift, Vol. 92, pp. 199-210.

Sjöbeck, M. (1933). Lövängskulturen i Sydsverige. Ymer, Vol. 53, pp. 33-66.

Sjörs, H. (1954). Slåtterängar i Grangärde Finnmark. (Summ.: Meadows in Grangärde Finnmark, SW Dalarna, Sweden.) Svenska Växtgeografiska Sällskapet, ISBN 91-7210-034-6, Uppsala.

Söderström, B., Svensson, B., Vessby, K., \& Glimskär, A. (2001). Plants, insects and birds in semi-natural pastures in relation to local habitat and landscape factors. Biodiversity and Conservation, Vol. 10, pp. 1839-1863.

Sporrong, U. (1971). Kolonisation, Bebyggelseutveckling och Administration : Studier i Agrar Kulturlandskapsutveckling Under Vikingatid och Tidig Medeltid med Exempel frain Uppland och Närke, Doctoral thesis, Department of Human Geography, Stockholm University. 
Stanners, D. \& Bourdeau, P. (1995). Europe's Environment. The Dobris Assessment. European Environment Agency, Copenhagen.

Svensson, B. M. \& Carlsson, B. A. (2005). How can we protect rare hemiparasitic plants? Early-flowering taxa of Euphrasia and Rhinanthus on the Baltic island of Gotland. Folia Geobotanica, Vol. 40, pp. 261-272.

Swedish Board of Agriculture (2007). Environmental subsidiaries. http://www2.sjv.se/webdav/files/SJV/trycksaker/Jordbruksstod/JS61.pdf

Swedish Board of Agriculture. (2005). TUVA - Ängs- och betesmarksinventeringen (survey of semi-natural grasslands), 2-10-2011, Available from https://eidservice.sjv.se/tuva2/site/index.htm

Swedish University of Agricultural Sciences (2010), Redovisning av uppdrag om halvtidsutvärdering av Landsbygdsprogram för Sverige 2007-2013. Fourth National Report to the Convention on Biological Diversity, Sweden., Landsbygdsdepartementet Jo 10.013, Regeringsbeslut 2009-04-20, M2009/385/Na. http://www.sweden.gov.se/sb/d/13746/a/155799

Tollin, C. (1991). Ättebackar och ödegärden. De äldre lantmäterikartorna i kulturmiljövården. Riksantikvarieämbetet, 91-7192-819-7, Stockholm.

Tollin, C. (2004). When Sweden was put on the map. In European Rural Landscapes: Persistance and Change in a Globalising Environment., ed. H. Palang, pp. 191-208. Kluwer Academic Publisher.

Turnbull, L. A., Crawley, M. J., \& Rees, M. (2000). Are plant populations seed-limited? A review of seed sowing experiments. Oikos, Vol. 88, pp. 225-238.

Valtonen, A. \& Saarinen, K. (2005). A highway intersection as an alternative habitat for a meadow butterfly: effect of mowing, habitat geometry and roads on the ringlet (Aphantopus hyperantus). Annales Zoologici Fennici, Vol. 42, pp. 545-556.

Van Andel, J., Bakker, J. P., \& Grootjans, A. P. (1993). Mechanisms of vegetation succession: a review of concepts and perspectives. Acta Botanica Neerlandica, Vol. 42, pp. 413433.

Vestbö-Franzén, A. (2004). Råg och Rön. Om mat, människor och landskapsförändringar i norra Småland, ca 1550-1700. Jönköpings läns museum, Jönköping.

von Linné, C. (1741). Carl von Linnés öländska och gotländska resa 1741.

Wallin, L. (2007). Plant population dynamics and conservation in wooded hay-meadows, Department of Ecology and Evolution, Plant Ecology, Uppsala University.

Watt, T. A. \& Gibson, C. W. D. (1988). The Effects of Sheep Grazing on Seedling Establishment and Survival in Grassland. Vegetatio, Vol. 78, pp. 91-98.

Webb, N. R. (1998). The traditional management of European heathlands. Journal of Applied Ecology, Vol. 35, pp. 987-990.

Welinder, S., Pedersen, E. A., \& Widgren, M. (1998). Jordbrukets första femtusen år. 4000 f.Kr1000 e.Kr Natur och Kultur/LTs förlag, 91-27-35542-X, Uppsala.

Willcox, E. V., Tanner, G. W., Giuliano, W. M., \& McSorley, R. (2010). Avian Community Response to Grazing Intensity on Monoculture and Mixed Florida Pastures. Rangeland Ecology \& Management, Vol. 63, pp. 203-222.

Wissman, J. (2006). Grazing regimes and plant reproduction in semi-natural grasslands, Doctoral thesis, Acta Universitatis Agriculturae Sueciae, No. 2006:40. 


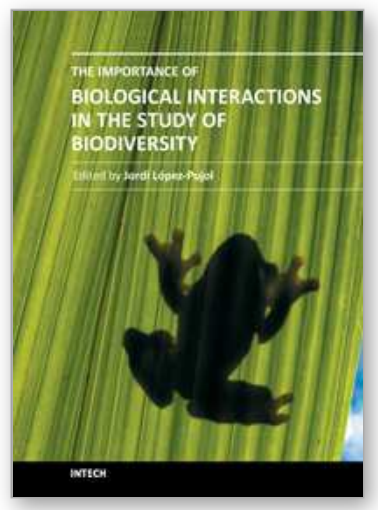

\section{The Importance of Biological Interactions in the Study of Biodiversity}

Edited by Dr. Jordi LÃ $\tilde{\beta}^{3}$ ez-Pujol

ISBN 978-953-307-751-2

Hard cover, 390 pages

Publisher InTech

Published online 22, September, 2011

Published in print edition September, 2011

The term biodiversity defines not only all the variety of life in the Earth but also their complex interactions. Under the current scenario of biodiversity loss, and in order to preserve it, it is essential to achieve a deep understanding on all the aspects related to the biological interactions, including their functioning and significance. This volume contains several contributions (nineteen in total) that illustrate the state of the art of the academic research in the field of biological interactions in its widest sense; that is, not only the interactions between living organisms are considered, but also those between living organisms and abiotic elements of the environment as well as those between living organisms and the humans.

\section{How to reference}

In order to correctly reference this scholarly work, feel free to copy and paste the following:

Eva Gustavsson, Anna Dahlström, Marie Emanuelsson, Jörgen Wissman and Tommy Lennartsson (2011). Combining Historical and Ecological Knowledge to Optimise Biodiversity Conservation in Semi-Natural Grasslands, The Importance of Biological Interactions in the Study of Biodiversity, Dr. Jordi LÃ3pez-Pujol (Ed.), ISBN: 978-953-307-751-2, InTech, Available from: http://www.intechopen.com/books/the-importance-ofbiological-interactions-in-the-study-of-biodiversity/combining-historical-and-ecological-knowledge-to-optimisebiodiversity-conservation-in-semi-natural-

\section{INTECH}

open science | open minds

\author{
InTech Europe \\ University Campus STeP Ri \\ Slavka Krautzeka 83/A \\ 51000 Rijeka, Croatia \\ Phone: +385 (51) 770447 \\ Fax: +385 (51) 686166 \\ www.intechopen.com
}

\author{
InTech China \\ Unit 405, Office Block, Hotel Equatorial Shanghai \\ No.65, Yan An Road (West), Shanghai, 200040, China \\ 中国上海市延安西路65号上海国际贵都大饭店办公楼405单元 \\ Phone: +86-21-62489820 \\ Fax: +86-21-62489821
}


(C) 2011 The Author(s). Licensee IntechOpen. This chapter is distributed under the terms of the Creative Commons Attribution-NonCommercialShareAlike-3.0 License, which permits use, distribution and reproduction for non-commercial purposes, provided the original is properly cited and derivative works building on this content are distributed under the same license. 